\title{
CLINICAL, LABORATORY AND RADIOLOGICAL PROFILE OF RE-TREATMENT TUBERCULOSIS
}

\author{
Ankit Jain ${ }^{1}$, Suma K. $R^{2}$
}

1 Postgraduate Student, Department of General Medicine, Sri Siddhartha Medical College and Hospital, Tumkur, Karnataka. 2Professor, Department of General Medicine, Sri Siddhartha Medical College and Hospital, Tumkur, Karnataka.

\section{BACKGROUND} ABSTRACT

Re-treatment tuberculosis has emerged as a major threat to global TB control efforts in recent years. Facilities for its diagnosis and treatment are limited in many high-burden countries including India. Screening and identification of re-treatment tuberculosis patients is very important, as they are the main source of transmission of MDR-tuberculosis to others who may need prolonged treatment with costly second line drugs. Inappropriate and inadequate treatment of re-treatment tuberculosis patient leads to the emergence of multi-drug resistance.

This study aims at finding the clinical, laboratory and radiological profile of re-treatment tuberculosis as well as the risk factors associated with them to help in early diagnosis and treatment of these groups of patients.

\section{MATERIALS AND METHODS}

This is a descriptive study. The present study includes 22 patients categorised as re-treatment tuberculosis according to RNTCP guidelines and undergoing treatment under RNTCP were taken in the study at Sri Siddhartha Medical College, Tumkur, Karnataka from $1^{\text {st }}$ January 2016 to $31^{\text {st }}$ August 2017. Patients were subjected to clinical examination, laboratory and radiological investigations.

\section{RESULTS}

Total of 22 patients were included in the study. Male: Female ratio for re-treatment tuberculosis was 4.5: 1. Most of the patients of re-treatment tuberculosis belonged to the age group of $>51$ years 10 (45.4\%). Among re-treatment patients, 50\% were failures, $31.8 \%$ defaulter and $18.1 \%$ relapse. Most common clinical presentation in re-treatment tuberculosis (90.9\%) was pulmonary tuberculosis and $81.8 \%$ were sputum positive. 95.4\% patients had cough, $81.8 \%$ had breathlessness and $63.6 \%$ had fever. Most common clinical sign on general physical examination in this study was 10 (45.4\%) pallor, followed by 5 (22.7\%) icterus, 4 (18.8\%) lymphadenopathy and 4 (18.8\%) cyanosis. Most common radiological finding on chest x-ray in re-treatment tuberculosis was infiltration 9 (40.9\%), followed by cavity $6(27.2 \%)$, and fibrosis $3(13.6 \%)$. Many of the cases had comorbid conditions like 45.4\% Anaemia, 36.3\% Malnutrition, 13.6\% Alcoholic, 13.6\% CKD, 18.1\% DM and 4.5\% HIV.

\section{CONCLUSION}

Re-treatment TB patients are emerging challenges to TB controls as they present with more severe disease and are more likely to have co-morbid conditions like DM, HIV, CKD, ALD and malnutrition. This study brought out the relationship between them. This study also shows that pulmonary TB is the most common site and many patients have sputum 3+ on microscopy. These patients need prolonged treatment with more number of drugs, thereby leading to more adverse reactions.

\section{KEYWORDS}

Re-treatment TB, MDR-TB, CBNAAT etc.

HOW TO CITE THIS ARTICLE: Jain A, Suma KR. Clinical, laboratory and radiological profile of re-treatment tuberculosis. J. Evolution Med. Dent. Sci. 2018;7(18):2218-2221, DOI: 10.14260/jemds/2018/499

\section{BACKGROUND}

Tuberculosis or TB, which is caused by bacteria Mycobacterium tuberculosis complex, is one of the oldest diseases known to affect humans and a major cause of death worldwide. This disease most often affects the lungs, although other organs are involved in upto one-third cases. Transmission usually takes place through the airborne spread of droplet nuclei produced by patients with infectious pulmonary tuberculosis. ${ }^{1}$

'Financial or Other Competing Interest': None.

Submission 27-01-2018, Peer Review 14-04-2018,

Acceptance 20-04-2018, Published 30-04-2018.

Corresponding Author:

Ankit Jain,

Room No. 20, PG Boys Hostel (Jeevika),

Sri Siddhartha Medical College and Hospital,

Tumkur, Karnataka.

E-mail: ankit_jainratlam@yahoo.in

DOI: $10.14260 /$ jemds/2018/499

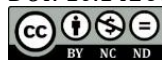

Overall, a relatively small proportion (5 - 15\%) of the estimated 1.7 billion people infected with M. tuberculosis will develop TB disease during their lifetime. However, the probability of developing TB disease is much higher among people infected with HIV and also higher among people affected by risk factors such as undernutrition, diabetes, smoking and alcohol consumption. ${ }^{2}$

TB is the ninth leading cause of death worldwide and the leading cause from a single infectious agent, ranking above HIV/ AIDS. An estimated 10.4 million people fell ill with TB in 2016: $90 \%$ were adults, $65 \%$ were males and $10 \%$ were people living with HIV. In 2016, 6.3 million new cases of TB were reported (up from 6.1 million in 2015), equivalent to $61 \%$ of the estimated incidence of 10.4 million. ${ }^{2}$

In $2016,39 \%$ of the 3.6 million new bacteriologically confirmed and previously treated TB cases notified globally were reported to have been tested for resistance to rifampicin, up from $31 \%$ in 2015 . Coverage was 33\% for new TB patients and $60 \%$ for previously treated TB patients. ${ }^{2}$ 
Globally in 2016, an estimated 4.1\% (95\% confidence interval [CI]: 2.8 - 5.3\%) of new cases and 19\% (95\% CI: 9.8 $27 \%$ ) of previously treated cases had MDR/RR-TB. ${ }^{2}$

India accounts for one-fourth of the global TB burden. In 2015, an estimated 28 lakh cases occurred, and 4.8 lakh people died due to TB. India bears second highest number of estimated HIV associated TB in the world. An estimated 1.1 lakh HIV associated TB occurred in 2015 and 37,000 estimated number of patients died among them. ${ }^{3}$

Total of 68,462 cases were notified in 2016 in the state of Karnataka, out of which 59,732 (87\%) were from public sector and $8,730(13 \%)$ were from private sector. Out of 59,732 TB patients notified from public sector, 49,814 (83\%) patients were of pulmonary tuberculosis and 9,918 (17\%) patients of extrapulmonary tuberculosis. Out of these cases, 47,145 (79\%) were new cases and 12,587 (21\%) were previously treated cases. ${ }^{3}$

The primary aim of the tuberculosis (TB) control programmes across the world is to reduce mortality and morbidity due to $\mathrm{TB}$ by interrupting the chain of $\mathrm{TB}$ transmission. Re-treatment cases (TB patients who have been previously treated with anti-TB drugs for at least a month), are a challenge to this primary aim of the TB control programmes. These patients comprise of relapse, treatment after failure, treatment after default and re-treatment other cases. Re-treatment cases emerge mostly as a result of inadequate and improper treatment of the new-TB cases. When compared to new cases, re-treatment cases require longer and more complicated treatment, are more likely to harbour and transmit drug-resistant $\mathrm{TB}$, and are likely to have poor treatment outcomes including increased risk of death. 4

There is utmost need to study the re-treatment tuberculosis patients, as inappropriate treatment can lead to patients remaining infectious and becoming a potential source of multi-drug resistance.

As the criteria for diagnosis of re-treatment patients has been simplified and CBNAAT machines have been made widely available, there has been a recent surge in the cases of re-treatment tuberculosis. So this study is undertaken to note the typical clinical, radiological and laboratory characteristics including the risk factors of re-treatment tuberculosis patients so as to help in its early detection and treatment.

\section{Aims and Objectives}

Aim of the study is to study the clinical, laboratory and radiological profile of re-treatment tuberculosis patients. An objective of the study is to study the clinical, laboratory and radiological profile as well as associated conditions and risk factors in patients with re-treatment tuberculosis.

\section{MATERIALS AND METHODS}

This is a descriptive study. The present study includes 22 patients categorised as re-treatment tuberculosis according to RNTCP guidelines and undergoing treatment under RNTCP were taken in the study at Sri Siddhartha Medical College Tumkur, Karnataka from $1^{\text {st }}$ January 2016 to $31^{\text {st }}$ August 2017. Detailed history regarding the illness was recorded. A thorough physical examination of all system was carried out. Appropriate laboratory and radiological investigation details were recorded. All patients were assigned categories as per RNTCP. Informed consent of all patients was taken in our study.

\section{Inclusion Criteria}

All patients aged $>18$ years who are diagnosed to have retreatment tuberculosis according to RNTCP guidelines.

\section{Exclusion Criteria}

- Extrapulmonary tuberculosis patients undergoing treatment under CAT-1 of RNTCP.

- $\quad$ All patients were diagnosed to have MDR tuberculosis.

\section{Statistical Method}

The data obtained from the patients with regard to clinical, radiographic and laboratory investigations was presented in tabulated forms. The numbers were expressed in percentages.

\section{RESULTS}

\begin{tabular}{|c|c|c|c|c|}
\hline Age & Males & Females & Re-treatment (n=22) & (\%) \\
\hline$<40$ & 3 & 0 & 3 & 13.6 \\
\hline $41-50$ & 7 & 2 & 9 & 40.9 \\
\hline$>51$ & 8 & 2 & 10 & 45.4 \\
\hline
\end{tabular}

\begin{tabular}{|c|c|c|c|c|}
\hline Types & Males & Females & Total (n=22) & (\%) \\
\hline Failure & 9 & 2 & 11 & $50 \%$ \\
\hline Defaulter & 7 & 0 & 7 & $31.8 \%$ \\
\hline Relapse & 2 & 2 & 4 & $18.1 \%$ \\
\hline
\end{tabular}

Table 2. Types of Re-treatment Tuberculosis

\begin{tabular}{|c|c|c|}
\hline Site of TB & $\begin{array}{c}\text { Re-treatment TB } \\
(\mathbf{n = 2 2})\end{array}$ & Percentage \\
\hline Pulmonary TB & 20 & $90.9 \%$ \\
\hline Extrapulmonary TB & 2 & $9 \%$ \\
\hline
\end{tabular}

Table 3. Site of Tuberculosis observed in Re-treatment Tuberculosis

\begin{tabular}{|c|c|c|}
\hline Grading of Sputum & Re-treatment TB (n=22) & (\%) \\
\hline Absent & 4 & 18.1 \\
\hline $1+$ & 0 & 0 \\
\hline $2+$ & 9 & 40.9 \\
\hline $3+$ & 9 & 40.9 \\
\hline Table 4. Sputum Analysis observed in Re-treatment \\
Tuberculosis \\
\hline
\end{tabular}

\begin{tabular}{|c|c|c|}
\hline Symptoms & $\begin{array}{r}\text { Present in Re-treatment } \\
\text { TB (n=22) }\end{array}$ & $\begin{array}{c}\text { Percentage } \\
\text { (\%) }\end{array}$ \\
\hline Cough & 21 & 95.4 \\
\hline Breathlessness & 18 & 81.8 \\
\hline Fever & 14 & 63.6 \\
\hline Chest pain & 5 & 22.7 \\
\hline Pain abdomen & 1 & 4.5 \\
\hline Seizures & 1 & 4.5 \\
\hline Low backache & 1 & 4.5 \\
\hline Discharging wound & 1 & 4.5 \\
\hline
\end{tabular}

Table 5. Symptoms observed in Re-treatment Tuberculosis 


\begin{tabular}{|c|c|c|}
\hline Signs & $\begin{array}{c}\text { Present in Re-treatment } \\
\text { TB (n=22) }\end{array}$ & (\%) \\
\hline Pallor & 10 & 45.4 \\
\hline Icterus & 5 & 22.7 \\
\hline Lymphadenopathy & 4 & 18.8 \\
\hline Cyanosis & 4 & 18.8 \\
\hline Gibbus & 1 & 4.5 \\
\hline $\begin{array}{c}\text { Tenderness lumbar } \\
\text { spine }\end{array}$ & 1 & 4.5 \\
\hline \multicolumn{2}{|c|}{ Table 6. Signs observed in Re-treatment Tuberculosis } \\
\hline
\end{tabular}

\begin{tabular}{|c|c|c|}
\hline $\begin{array}{l}\text { Laboratory } \\
\text { Parameter }\end{array}$ & $\begin{array}{c}\text { Present in Re-treatment } \\
\text { TB }(n=22) \\
\end{array}$ & $(\%)$ \\
\hline \multicolumn{3}{|l|}{ 1. Haemoglobin(gm/dL) } \\
\hline a. $<10$ & 6 & 27.2 \\
\hline b. $10.1-12$ & 8 & 36.3 \\
\hline c. $>12$ & 7 & 31.8 \\
\hline \multicolumn{3}{|l|}{ 2. Total count } \\
\hline (cells/cumm) & 1 & 4.5 \\
\hline a. $<4000$ & 7 & 31.8 \\
\hline $\begin{array}{l}\text { b. } 4000-11000 \\
\text { c. }>11000\end{array}$ & 14 & 63.6 \\
\hline \multicolumn{3}{|l|}{$\frac{\text { c. }>11000}{3 . \mathrm{RBS}(\mathrm{mg} / \mathrm{dL})}$} \\
\hline $\begin{array}{l}\text { 3. RBS (mg/dL) } \\
\text { a. }<110\end{array}$ & 9 & 40.9 \\
\hline \multicolumn{3}{|l|}{ b. $110-140$} \\
\hline \multicolumn{3}{|l|}{ c. $>140$} \\
\hline \multicolumn{3}{|l|}{ 4. ESR } \\
\hline a. $<40$ & 15 & 68.1 \\
\hline b. $40-60$ & 6 & 27.2 \\
\hline c. $>60$ & 1 & 4.5 \\
\hline \multicolumn{3}{|l|}{ 5. Blood Urea $(\mathrm{mg} / \mathrm{dL})$} \\
\hline a. $<30$ & 11 & 50 \\
\hline b. $30-50$ & 10 & 45.4 \\
\hline c. $>50$ & 1 & 4.5 \\
\hline \multicolumn{3}{|l|}{ 6. Serum Creatinine } \\
\hline (mg/dL) & 19 & 86.3 \\
\hline $\begin{array}{l}\text { a. }<1.4 \\
\text { b. }>1.4\end{array}$ & 3 & 13.6 \\
\hline 7. HIV positive & 1 & 4.5 \\
\hline \multicolumn{3}{|c|}{$\begin{array}{c}\text { Table 7. Laboratory Tests observed in Re-treatment } \\
\text { Tuberculosis }\end{array}$} \\
\hline
\end{tabular}

\begin{tabular}{|c|c|c|c|}
\hline Investigation & Features & $\mid \begin{array}{c}\text { Present in Re- } \\
\text { treatment TB } \\
(\mathrm{n}=22)\end{array}$ & $\begin{array}{c}\text { Percentage } \\
\text { (\%) }\end{array}$ \\
\hline \multirow{6}{*}{$\begin{array}{c}\text { X-Ray } \\
\text { Features }\end{array}$} & Normal & 1 & 4.5 \\
\hline & $\begin{array}{c}\text { Infiltration } \\
\text { a. Unilateral } \\
\text { b. Bilateral }\end{array}$ & $\begin{array}{l}8 \\
1\end{array}$ & $\begin{array}{c}36.3 \\
4.5\end{array}$ \\
\hline & Collapse & 1 & 4.5 \\
\hline & Fibrosis & 3 & 13.6 \\
\hline & $\begin{array}{c}\text { Cavity } \\
\text { a. Unilateral } \\
\text { b. Bilateral }\end{array}$ & $\begin{array}{l}4 \\
2\end{array}$ & $\begin{array}{c}18.1 \\
9\end{array}$ \\
\hline & $\begin{array}{l}\text { Pleural } \\
\text { Effusion }\end{array}$ & 0 & 0 \\
\hline USG & Abscess & 1 & 4.5 \\
\hline MRI & Pott's spine & 1 & 4.5 \\
\hline
\end{tabular}

\section{DISCUSSION}

This study was done to know the clinical, laboratory and radiological profile as well as the associated risk factors of retreatment patients who were diagnosed and registered under RNTCP Department at Sri Siddhartha Medical College Hospital and Research Centre, Tumkur, Karnataka.

Among total 22 cases of re-treatment registered during the study period, 18 (81.8\%) were males and 4 (18.1\%) were females. In this study male-to-female ratio of re-treatment TB is 4.5: 1 , which shows a male predominance similar to other studies like Srinath Sharath et al 5 in Andhra Pradesh, which shows $67 \%$ male patients and Sandeep Naveen et al 6 at Chandigarh shows $63.9 \%$ males with male: female ratio of 1.8: 1, while Ugra Srinath et $\mathrm{al}^{7}$ shows $80 \%$ male predominance.

Above data is different from other studies in showing a female predominance like Hannock, Henry et $\mathrm{al}^{8}$ at Malawi which shows $60 \%$ females in their study.

In this study $10(45.4 \%)$ cases belonged to the age group of $>51$ years, which highlights the socio-economic burden of re-treatment tuberculosis on the society. Similar study by Srinath Sharath et al ${ }^{5}$ in Andhra Pradesh shows $88 \%$ patients were in the age group of 15 - 64 years. Sandeep Naveen et al ${ }^{6}$ at Chandigarh conducted a study, which shows the mean ages of males and females were $38.79 \pm 14.4$ and $30.84 \pm 15.85$ years respectively, while Ugra Srinath et $\mathrm{al}^{7}$ conducted a study which shows that the median age was 38 years.

Most common clinical presentation in our study was 21 (95.4\%) cough followed by $18(81.8 \%)$ breathlessness and 14 (63.6\%) fever similar to Abinash Kaushik et $\mathrm{al}^{9}$ in west Bengal showing cough (92.1\%) and fever (84.2\%) followed by weight loss, anorexia and haemoptysis.

Most of the re-treatment tuberculosis patients in our study had $81.8 \%$ sputum smear positivity similar to Ugra Srinath et $\mathrm{al}^{7}$ study, which shows $79.4 \%$ were sputum smearpositive.

In our study 11 (50\%) were re-treatment failure, 7 (31.8\%) defaulters and $4(18.1 \%)$ were relapse cases, while studies like Srinath, Sharath et al ${ }^{5}$ in Andhra Pradesh showed $78 \%$ were relapses, $73 \%$ were treatment after default and $59 \%$ were failure cases, while study by Karma, Luna et al ${ }^{10}$ in Sikkim shows relapse cases were $63.8 \%$, failure cases were $20.8 \%$ and treatment after default cases were $15.2 \%$.

The most common x-ray feature in our study was 9 (40.9\%) infiltration followed by $6(27.2 \%)$ cavitatory lesions (4 unilateral and 2 bilateral). The study done by Abinash Kaushik et $\mathrm{al}^{9}$ in West Bengal shows most common x-ray feature as cavitatory lesions, which accounted for $60.8 \%$ of the cases.

\begin{tabular}{|c|c|c|c|}
\hline $\begin{array}{c}\text { Co-morbid } \\
\text { Conditions }\end{array}$ & $\begin{array}{c}\text { Present } \\
\text { Study }\end{array}$ & $\begin{array}{c}\text { Abinash Kaushik } \\
\text { et al }^{\mathbf{9}}\end{array}$ & $\begin{array}{c}\text { Kelly Ouafae } \\
\text { et al11 }\end{array}$ \\
\hline HIV & $4.5 \%$ & $2.6 \%$ & $1 \%$ \\
\hline Alcoholic & $13.6 \%$ & $30.2 \%$ & $2 \%$ \\
\hline CKD & $13.6 \%$ & & \\
\hline DM & $18.1 \%$ & $9.2 \%$ & \\
\hline Anaemia & $45.4 \%$ & & \\
\hline Malnutrition & $36.3 \%$ & & \\
\hline
\end{tabular}

Table 9. Comparison of Co-morbid Conditions associated with Tuberculosis

The above study shows the demographic characteristics of patients like age and gender distribution are similar to those in other study. The clinical characteristics also shows that most patients present with pulmonary tuberculosis in retreatment tuberculosis cases and most of them turn out to be sputum positive and thereby are highly infectious. This study also shows that these patients have more extensive disease radiologically and also many of them have other co-morbid 
conditions like DM, HIV, CKD, ALD, anaemia and malnutrition, etc. which makes them more prone to relapses or reactivation of tuberculosis. These patients also need more number of drugs and for prolonged period, which may lead to more number of adverse drug reactions and also are more likely to discontinue treatment. This study also shows that most of the cases in re-treatment tuberculosis were failure cases, thereby strengthening the fact that incomplete and inadequate treatment are the main cause of emergence of MDR-TB.

The introduction of daily regimen will probably reduce the number of failure TB cases and also with the more availability of CBNAAT machines aid in early identification and treatment of MDR-TB cases and with the help of NIKSHAY these TB cases are better monitored until the end of treatment.

\section{CONCLUSION}

Re-treatment tuberculosis patients are emerging challenges to TB controls as they present with more severe disease and are more likely to have co-morbid conditions like DM, HIV, CKD, ALD and malnutrition. This study brought out the relationship between them. They also need prolonged treatment with more number of drugs, thereby leading to more adverse reactions.

This study also shows that pulmonary $\mathrm{TB}$ is the most common site and many patients have sputum $3+$ on microscopy. They form the important source of spread of infection to other individuals and also form source for MDRTB which may worsen the existing situation if they are not diagnosed early and treated adequately.

The new change in regimen to daily treatment and also with the availability of more CBNAAT machines and use of NIKSHAY for monitoring of patient will be a big step towards early diagnosis and complete treatment of this group of patients.

Further studies need to be done to know the outcome of tuberculosis patients after starting of daily anti-tubercular treatment regimen and to know the impact of daily regimen in these group of patients under RNTCP.

\section{REFERENCES}

[1] Raviglione MC. Harrison's principle of internal medicine. Kaasper DL, Hauser SL, Jameson JL, et al. (eds). Harrison's principle of internal medicine. 19th edn. USA: McGraw-Hill, 2015:pp 1102.
[2] Raviglione M. Global tuberculosis report. 22nd edn Geneva, Switzerland: World Health Organization; 2017. Accessed from: http://apps.who.int/iris/bitstream/10665/259366/1 /9789241565516-eng.pdf?ua=1.

[3] Prasad J, Khaparde SD. TB INDIA 2017 RNTCP Annual Status Report. New Delhi: Central TB Division, Directorate General of Health Services; 2017. https://tbcindia.gov.in/WriteReadData/TB\%20 India\%202017.pdf (accessed 22 November 2017).

[4] Sachdeva KS, Satyanarayana S, Dewan PK, et al. Source of previous treatment for re-treatment TB cases registered under the national TB control programme, India, 2010. PLoS One 2011;6(7):e22061.

[5] Srinath S, Sharath B, Santosha K, et al. Tuberculosis 'retreatment others': profile and treatment outcomes in the state of Andhra Pradesh, India. Int J Tuberc Lung Dis 2011;15(1):105-9.

[6] Sarpal SS, Goel NK, Kumar D, et al. Gender disparities in retreatment patients of tuberculosis: a north Indian study. J Nat Sci Biol Med 2015;6(1):63-6.

[7] Jha UM, Satyanarayana S, Dewan PK, et al. Risk factors for treatment default among re-treatment tuberculosis patients in India, 2006. PLoS One 2010;5(1):e8873.

[8] Tweya H, Kanyerere H, Ben-Smith A, et al. Retreatment tuberculosis cases categorised as "other": are they properly managed? PLoS One 2011;6(12):e28034.

[9] Agarwala A, Saha K, Shamim S, et al. The profile and treatment outcomes of sputum smear positive pulmonary tuberculosis re-treatment cases, in a district medical college of West Bengal, India. The Journal of Association of Chest Physicians 2014;2(2):63-7.

[10] Dolma KG, Adhikari L, Dadul P, et al. A study on the assessment of retreatment tuberculosis patients attending the DOTS centre in Sikkim, India from 20022010. Research Journal of Infectious Diseases 2013.

[11] Dooley KE, Lahlou O, Ghali I, et al. Risk factors for tuberculosis treatment failure, default, or relapse and outcomes of retreatment in Morocco. BMC Public Health 2011;11(140). 